\title{
Effectiveness of Woolwich Massage to Meet Adequacy of Breast Milk in Newborns
}

\author{
Septi Nurvitasari $\left.{ }^{1}\right)$, Rev. Pujiastuti ${ }^{2}$ ), Arfiana ${ }^{2}$ ) \\ Septinurvitasari3@gmail.com \\ Health Polytechnic of Semarang \\ Magelang Midwifery Graduate Program
}

\begin{abstract}
Background: The recommendations of the United Nations Children's Fund (UNICEF) and the World Health Organization (WHO) in an effort to decrease the morbidity and mortality of infants and children, the child should be fed only breast milk (ASI) for at least 6 months. The highest failure of breastfeeding occurs in the first days after birth due to the low production of milk, so the need to increase milk production in the first days after birth.

Purpose: The purpose of this study is to determine the effectiveness of Woolwich Massage to meet the adequancy of breast milk in newborn.

Methods: This is a prospective study with quasi experiment research design. The population were primipara postpartum from day 8 to day 14 . Technique of sampling using random technique that is side cluster. All samples were divided into two groups is 18 respondents as intervention group and 18 respondents as control group.

Results: The results of this study indicate the effect of woolwich massage on meet the adequancy of breast milk in the newborn and significant difference in infant weight changes in the intervention group and control group ( $p$ value $=0.000<0.05$ ). The adequency of breast milk can be assessed by monitoring the baby's weight.

Conclusion: It is expected midwifes can teach woolwich massage techniques to ensure adequancy breast milk in the newborn. This effort can be a government policy to increase the coverage of exclusive breastfeeding in a region.
\end{abstract}

keyword: Woolwich Massage, Breast Milk, Newborn

1) Student of Midwifery Study Program of Magelang, Semarang Health Polytechnic

2) Lecturer of Midwifery Study Program of Magelang, Semarang Health Polytechnic

Background. Child health care efforts aimed at preparing future generations of healthy, intelligent, and quality and to reduce child mortality. Child health care efforts have made since the fetus is still in the womb, birth, after birth, and until the age of 18 years(Infodatin, 2014)

Based on the recommendations of the United Nations Children's Fund (UNICEF) and the World Health Organization (WHO) in an effort to decrease the morbidity and mortality of infants and children, the child should be fed only breast milk (ASI) for at least 6 months. Solid foods should be given after 6 month old baby and breastfeeding continues until the child is 2 years old(Infodatin, 2014)

According to the Demographic and Health Survey in 2012 the number of mothers breastfeeding as much as $42 \%$, but only $44 \%$ of $42 \%$ who get successful lactation in the first hour 
after birth and $62 \%$ from $42 \%$ in the first days after birth, and 50.8\% from $42 \%$ in first month. Early breastfeeding in the first hour after birth will stimulatethe increasing of prolactin inthe blood and reach the highest level in the first 45 minutes and can affect the breastfeeding till infant's age 6 months.

Based on (Indonesia Health Profile, 2016) the percentage of infants 0-5 months were get breast milk exclusively $54.0 \%$, while infants who are get breast milk exclusively until 6 months of age is $29.5 \%$. Refer to the strategic plan targets in 2016 which amounted to $42 \%$, so nationwide coverage breastfeeding until the age of 6 months of $29.5 \%$ has not reached the target. Exclusive breastfeeding based on Government Regulation No. 33 of 2012 is the breast milk which given to babies from birth until 6 months, without adding or replacing with other food or drink (except drugs, vitamins, and minerals). Breast milk contains colostrum, which is rich in antibodies for protein to the immune system and antibiotics in high quantities that exclusive breastfeeding can reduce the risk of death in infants.

Neonatal Mortality Rate (AKN) in Temanggung regency in 2016 reached 8.9 per 1,000 live births, which decreased from 2015 which was 11.2 per 1,000 live births. IMR stood at 3.8 per 1,000 live births, which is decrease rapidly of 2015, which reached 16.8 per 1,000 live births. Then Akaba at 5.4 per 1,000 live births, which decreased rapidly from 2015 that is 19 per 1,000 live births. This raises particular attention to efforts to reduce neonatal mortality rate because it the most contributed $(45 \%)$ of infant deaths in Temanggung regency in 2016.(Health profile of Temanggung, 2016)
The biggest causes of infant mortality in the Temanggung regency2016, among which the incidence of low birth weight were 51 cases, and the second leading cause of infant mortality is due to the other factors(newborn care at homeissue, lethargy, baby lazy drinking milk, supplemental feeding early, etc.), followed by asphyxia cases were 21 cases, followed by 10 cases konginetal disorders, pneumonia and diarrhea respectively of 4 cases and sepsis as well as the respective ikherus also 1 case. As for the greatest causes of child mortality is because of another factors (leukemia, dipsneu, drowned in the pool, downsyndrome, burns, hydrocepalus, aspiration, pneumonia, febrile seizures, eye cancer, etc.) as many as 15 cases,(Health profile of Temanggung, 2016),

Percentage of exclusive breastfeeding at Temanggung regency 2016 in infants $0-6$ months is $83.6 \%$. Just a little difference when compared to 2015 amounted to $83.1 \%$. The lowest percentage of exclusive breastfeeding in theKedu Public Health Centerat $65.0 \%$.(Health profile of Temanggung, 2016)

According to research (Pranajaya, 2013) the best age for a mother to produce breast milk is currently healthy reproductive age. Based on his research showed that $64.7 \%$ (110) of the respondents were healthy reproductive age have enough milk production and $42.1 \%$ (8) of the respondents were on unhealthy reproductive age are have enough breast milk production. While inprimiparous parity mother,breast milk production are $76.6 \%$ enough. Primiparous mothers have more anxiety that affect the hormones that help breast milk production. Based on his research, namely $76.6 \%$ (76) of 
respondents primiparas have enough milk production and concluded that there is significant correlation between parity with milk production.

According to research (Pamuji, 2014)to overcome the problem of lactation is possible use intervention that is a combination of Woolwich massage methods and endorphine to increase prolactin and oxytocin reflex. Woolwich massage done at precisely the lactiferous sinus area $1-1.5 \mathrm{~cm}$ above the areola for approximately 15 minutes, with the aim of removing the breast milk that of the lactiferous sinus. The massage will stimulate the nerve cells in the breast, the stimulus is forwarded to the hypothalamus and respondedby the anterior pituitary to secrete the anterior pituitary to secrete the prolactin hormone which will be flowed by blood to the breast myoepithelial cells to produce milk and to prevent breast inflamation or mastitis.

Based on the results of a preliminary study in Puskesmas Kedu conducted interviews with coordinating midwife, nutritionist and four of the seven mothers primiparous who are breastfeeding but not exclusive breastfeeding say the reason is because spending her breast milk are less and worry that their babies will be lack of breast milk, so often time babies given formula. It shown that the primiparous mothers who are breastfeeding more experience problems regarding the production of breast milk than in multiparous lactating mothers, so the researchers will conduct research with the aim to prove the effectiveness of Woolwich massage to fulfill the adequacy of breast milk in Newborns in Kedu Public Health Center.
Objective. All thewomen breastfeedingin Kedu Public Health Center.

Methods. This study uses a quasiexperimental research design. This study aims to determine the effectiveness of Woolwich massage to fulfill their milk to the newborn. This study design using the Comparison of static groups design (Static Group Comparison). Where the experimental group received a treatment (X) followed by a second measurement or observation $(\mathrm{O} 2)$. The results of these observations then be controlled or compared with the observed results in the control group who did not receive treatment. This study using the MannWhitney test to determine differences in infant weight gain in the intervention group and the control group.

Result and Discussion. The intervention group had a weight gain with an increase of at least 300 grams, a maximum increase of 500 grams, and the average increase of 405.5 grams. In the intervention group Woolwich massage is known that the baby's weight increased more than the control group. Thus the effect of massage on the breast area to increase milk production, so that it can affect the baby's weight gain. This is according to research conducted(Machmudah, 2016)that the baby's weight on the respondents who get the lowest oketani and oxytocin massage after they got oketani and oxytocin massage on the seventh day is 2560 grams, the highest of 3990 grams, the average 3110 grams with a standard deviation of 396.75 . While the respondents who do not get oketani and oxytocin massage, the lowest birth weight after oketaniand oxytocin massage is 2600 grams, the 
highest of 4500 grams, the average 3221 grams with a standard deviation of 523.12

Woolwich massage method is a massage which doat the lactiferous sinus area $1-1.5 \mathrm{~cm}$ above the areola, with the aim to secreting the breast milkwhich located on the lactiferous sinus. The aim is to improve prolactin reflex that have important role in the breast milk production and also can improve the oxytocin reflex that have a role to smoother the breast milk flowed. Woolwich massage stimulatedthe myoepithelial cells around the mammary gland, the stimulation is forwarded to the hypothalamus and responded by the anterior pituitary to secrete the prolactin hormone which will be flowed to mammary myoepithelial cells to produce breast milk(Pamuji, 2014)

According to research (Liberty, 2017)based on a $t$ test sample, the results have showed that there were significant differences $(p=0.012<)$ production of breast milk (baby weight) between the control group (3021.88 \pm 159.88) with Woolwich massage treatment group $(3265.63 \pm 320.79)$, this difference was shown in the average of baby weight on the treatment group compared with control group.

Woolwich massage stimulated the myoepithelial cells around the mammary gland, the stimulation is forwarded to the hypothalamus and responded by the anterior pituitary to secreteprolactin hormone which will be flowed to mammary myoephithelial cells to produce the breast milk. Woolwich massage is one massage techniques to the breast in postpartum women which is recommended to improve prolactin reflexes and oxytocin reflex (let-down reflex). Woolwich massage can increase breast milk production, increase spending as well as the secretion of breast milk, and to prevent thebreast dam and mastitis(Pamuji, 2014)

Another primacy in this Woolwich massage technique is the massage techniques are simple,it can be done by the mother's self, the equipment is readily to get and does not require a long time to do, so it will make mother easy to do Woolwich massage. While the influece factors to increasing the prolactin levels are breast physical readiness or free of breast dam as well as mastitis(Pamuji, 2014)

Baby's weight gain in the control group.

The weight gain on control group with a minimum increase of 100 grams, the maximum increase of 300 grams, and the average increase of 238.88 grams. According to(Fatima, 2014)there are relationsof the frequency of exclusive breastfeeding during childbirth with weight gain of infants aged 0-6 weeks. Infants who received breast milk adequacy has a good weight gain after birth, good growth after the perinatal period, and reduce the risk of obesity.

The research show that the control group get a weight change. The baby weight changehappen because of several factors, such as the sufficient milk to the baby. Adequacy of breastfeeding is associated with how much mother can produce the breast milk. Lactation process is related to prolactin reflex and oxytocin reflex which give role in the breast milk production. Prolactin is released in pulses (pursatile). It's looks diurnal prolactin secretion rhythm, with higher levels in the blood during sleep. In the early post-partum period, bromocriptine, a dopamine D2 receptor agonist, causes prolactin level's reduction and eliminate the secretion of 
breast milk. Dopamine is associated with receptors in the pituitary and internalized which cause the increasing of prolactin in secretory granules. Prolactinassociated with the receptors in the secretory alveoli, work in some places to increase the synthesis of the milkcomponentsincluding casein, laktalbimin, and fatty acids. Oxytocin is associated with specific receptors on myoepithelial cells around the milkproducer cells and the longitudinal walls of the ducts. The contraction of the myoepithelial cells cause milk secretion into the duct, which become shorten because of longitudinal cells contraction. Contractions induced by oxytocin caused pressure waves in the breast and responsible punctured tingling sensation that arises during breastfeeding. If squirting reflex has been formed, breast milk can squirted spontaneously by both breast (Coad, 2007 ; h. 343)

In the control group had a different breastfeedingfrequency, more frequently, so the breast milk production will be better, this is according to research conducted by (Trio, 2015)that the results of analysisdatawhich has been done obtained as much as $63 \%$ of neonates with frequentlyfeeding can increase their weight gain, while as many as $37 \%$ of neonates couldn'tincrease their weight gain. Analysis of the data showed that the value of its $p$-value $(0.015)$ is smaller than the value $\alpha$ (0.05) which means that the frequency of feeding and weight change has a significant relation.

2. The difference of infant weight gain in the intervention group and the control group

The difference of infant weight gain in the control group and the intervention group obtained the significant value of $0.000(p<0.05)$, so that there is a difference statistically significant changes in body's weight between the control and intervention groups or a massage Woolwich or Ho rejected. The test results demonstrate the value of $Z=-5.251$, this means Woolwich massageeffective to increase milk production so as to increase the weight of the baby as much as 5 times

\section{Conclusion and Suggestions.}

\section{Conclusion}

1. Baby's weight increase in the intervention group reach 300 grams for the minimun, and 500 grams for the maximum, and the average is 405.5 grams.

2. Baby's weight increase in the control group can increase 100 grams at the minumum, and 300 grams at the maximum, and the average is 238.88 grams.

3. There are differences of baby's weight in the intervention group and the control group, according to the analysis results, weight gain changes on intervention group and control group have significant value of $0.000(\mathrm{p}<0.05)$, so there are statistically weight gain changes between the intervention group and control group or Ho rejected. This result show the value of $Z=-5.251$, this means that Woolwich massage effectively increase the breast milk production so can increase baby's weight 5 times.

\section{Suggestion}

1. For Mom

Postpartum mothers ought to looking for information and practicingWoolwich massage to increase breast milk production.

2. For Midwifery Practitioner

It is expected that health professionals, especially in the obstetrics department of Kedu 
health center to provide new innovations to postpartum mothers liketeach Woolwich massage techniques to increase breast milk production, especially in the first days after childbirth

3. For PublicHealth Centers

Public Health Center provide policy which givepostpartum mothers in Kedu public health centerregionto get puerperium services, especially in lactation term that is taught the new innovation in order to increase the breast milk such as teach woolwich massage

4. For Further Research

It is expected that further research can improve this research by increasing the number of research samples, assess the increase of breast milk production by more complete indicator, can give more control to interfere variables, increase research time, and looking for new innovations to increase the effectiveness of the method in this study.

\section{References.}

Fatimah. (2014). hubungan frekuensi pemberian asi eksklusif pada masa nifas dengan penambahan berat badan bayi usia 0-6 minggu, 4(2).

Infodatin. (2014). InfoDATIN Pusat Data dan Informasi Kementerian Kesehatan RI Situasi dan Analisis
ASI Eksklusif. Huanan Ligong Daxue Xuebao/Journal of South China University of Technology (Natural Science), 33(10). https://doi.org/10.1179/160784541 3Y.0000000140

Liberty. (2017). Pengaruh Pijat Woolwich Terhadap Produksi ASI Di BPM Appi Amelia Bibis Kasihan Bantul, (November), 243-250.

Machmudah. (2016). Kombinasi Pijat Oketani dan Oksitosin terhadap Parameter Produksi ASI pada Ibu Post Seksio Sesarea di Rumah Sakit Wilayah Kota Semarang.

Pamuji. (2014). Pengaruh Kombinasi Metode Pijat Woolwich dan Endorphine terhadap Kadar Prolaktin dan Volume ASI, 52.

Pranajaya. (2013). Determinan Produksi ASI pada Ibu Menyusui. Jurnal Keperawatan, IX(2), 227237.

Profil Kesehatan Indonesia. (2016). Profil Kesehatan Indonesia. https://doi.org/10.1111/evo.12990

Profil Kesehatan Kabupaten Temanggung. (2016). Profil Kesehatan Kabupaten Temanggung.

Trio. (2015). Hubungan Frekuensi Dan Lama Menyusu Dengan Perubahan Berat Badan Neonatus Di Wilayah Kerja Puskesmas Gandusari Kabupaten Trenggalek, $38-43$. 